\title{
Hubungan Tingkat Stres dengan Kualitas Tidur pada Ibu Preeklamsi di Wilayah Kerja Puskesmas Tempurejo-Jember
}

\section{(Relationship between Stress Level and Sleep Quality In Preeclampsia Women at Tempurejo, Jember)}

\author{
Dyan Ayu Pusparini, Dini Kurniawati, Enggal Hadi Kurniyawan \\ Fakultas Keperawatan Universitas Jember \\ JI.Kalimantan No.37, Kampus Tegalboto Jember Telp./Fax(0331) 323450 \\ e-mail korespondensi: dyanayupus@gmail.com
}

\begin{abstract}
Preeclampsia is some of the symptoms that occur in pregnancy, childbirth, and puerperal women, which are characterized by hypertension, edema, and increased proteinuria. Preeclampsia usually occurs when pregnancy enters the age of 20 weeks to 48 hours after the birth process. In that condition, there are undesirable complications during pregnancy that can make mothers more vulnerable to psychological disorders, one of which is stress. Stress experienced during pregnancy can affect the health of the baby and can also improve poor sleep quality. This study aims to analyze the relationship of stress levels with the quality of preeclampsia sleep in the Tempurejo Community Health Center in Jember. This research was conducted on 31 preeclampsia mothers using a correlational research design with a cross-sectional approach and total sampling techniques. Data collection using questionnaires stress and sleep quality. The results showed 19 (61.3)\% of respondents experienced mild stress, and 26 (83.9)\% experienced poor sleep quality. The results of data analysis using the spearmen statistical test obtained $p$-value 0.001 and $r=$ 0.894 , which means there is a relationship between stress levels and sleep quality or ha is accepted. $R$ value $=0.396$ means that the correlation between stress levels and sleep quality in preeclampsia has a positive correlation with weak correlation strength. Nursing implications for further research can intervene in interventions that can reduce stress levels with the quality of sleep in preeclampsia mothers to reduce the factors of preeclampsia.
\end{abstract}

Keywords: Preeclampsia, sleep quality, stress

\begin{abstract}
Abstrak
Preeklamsi adalah beberapa gejala yang timbul pada ibu hamil, bersalin dan nifas yang ditandai dengan hipertensi, edema, dan peningkatan proteinuria. Preeklamsi biasanya terjadi pada saat kehamilan memasuki umur 20 minggu hingga 48 jam setelah proses persalinan, pada kondisi tersebut terjadi komplikasi yang tidak diinginkan saat hamil yang dapat membuat ibu lebih rentan mengalami gangguan psikologis salah satunya yaitu stres. Stres yang dialami saat hamil dapat mempengaruhi kesehatan bayi dan juga dapat meningkatkan kualitas tidur yang buruk. Penelitian ini bertujuan untuk menganalisis hubungan tingkat stres dengan kualitas tidur ibu preeklamsi di Wilayah Kerja Puskesmas Tempurejo Kabupaten Jember. Penelitian ini dilakukan pada 31 ibu preeklamsi menggunakan desain penelitian korelasional dengan pendekatan cross sectional dan menggunakan teknik total sampling. Pengumpulan data menggunakan kuesioner stres dan kualitas tidur. Hasil penelitian menunjukkan $19(61,3) \%$ responden mengalami stres ringan dan $26(83,9) \%$ responden mengalami kualitas tidur yang buruk. Hasil analisa data menggunakan uji statistik spearmen didapatkan $p$ value 0,001 dan nilai $r=0,894$ yang artinya terdapat hubungan antara tingkat stres dengan kualitas tidur atau Ha diterima. Nilai $r=0,894$ mengartikan bahwa korelasi antara tingkat stres dengan kualitas tidur pada ibu preeklamsi memiliki arah korelasi positif dengan kekuatan korelasi sangat kuat. Implikasi keperawatan untuk penelitian selanjutnya dapat melakukan intervensi melakukan intervensi yang dapat mengurangi tingkat stres dengan kualitas tidur pada ibu preeklamsi sehingga dapat mengurangi faktor-faktor preeklamsi.
\end{abstract}

Kata kunci: Preeklamsi, Kualitas Tidur, dan Stress. 


\section{Pendahuluan}

Kesehatan pada ibu hamil merupakan salah satu aspek penting untuk diperhatikan dalam siklus kehidupan perempuan karena saat masa kehamilannya dapat mengalami komplikasi yang tidak diinginkan [1]. Salah satu kehamilan yang berisiko tinggi terjadi pada ibu hamil yang memiliki tekanan darah tinggi (preeklamsi). Hal tersebut merupakan salah satu penyebab morbiditas dan mortalitas pada ibu hamil sehingga meningkat angka kematian ibu (AKI) [2].

Preeklamsi adalah beberapa gejala yang timbul pada ibu hamil, bersalin dan nifas yang ditandai dengan hipertensi, edema, dan peningkatan protein uria. Preeklamsi biasanya terjadi pada saat kehamilan memasuki umur 20 minggu hingga 48 jam setelah proses persalinan. Preeklamsi merupakan salah satu faktor penyebab angka kematian ibu. Salah satu masalah kesehatan preeklamsi yang sering muncul adalah tekanan darah tinggi yaitu kenaikan diastolik $\geq 15 \mathrm{mmHg}$ atau kenaikan sistolik $\geq 30 \mathrm{mmHg}$ [3]. Menurut WHO tahun 2014, di dunia terdapat sekitar 585.000 ibu meninggal per tahunnya pada saat hamil atau bersalin dan $58,1 \%$ disebabkan preeklamsi.

Di Indonesia preeklamsi merupakan salah satu penyebab angka kematian ibu yang tinggi yaitu sebesar 24\% [4]. Angka kejadian preeklamsi di Jawa Timur tahun 2010 sebesar $26,92 \%$ yang meningkat menjadi $27,77 \%$ tahun 2011 dan $34,88 \%$ tahun 2012. Pada tahun 2014 preeklamsi merupakan masalah yang sering terjadi pada ibu hamil yaitu sebesar 31,04\% dan menjadi penyebab kematian ibu di Provinsi Jawa Timur [5].

Menurut penelitian yang dilakukan Lesmana dan Rahma tahun 2019 mengatakan pada tahun 2017 di Puskesmas Tempurejo dari 743 ibu hamil didapatkan hasil 27 ibu preeklamsi. Pada bulan Januari hingga April tahun 2018, 309 ibu hamil mengalami resiko preeklamsi. Setelah melakukan skrining ibu yang mengalami resiko preeklamsi sebanyak 211 (68,3\%), sehingga dapat disimpulkan ibu yang mengalami preeklamsi berjumlah 41 ibu hamil yang mengalami preeklamsi. Dari hasil data tersebut menunjukkan bahwa ibu hamil yang mengalami preeklamsi dari tahun 2017 hingga tahun 2018 di Puskesmas Tempurejo meningkat [6].

Tanda dan gejala pada ibu preeklamsi biasanya diikuti bertambahnya berat badan yang berlebih diikuti edema, hipertensi, sakit kepala di daerah frontal, diplopia, penglihatan kabur, nyeri epigastrium, mual dan muntah [3]. Beberapa tanda dan gejala tersebut menyebabkan gangguan rasa nyaman sehingga ibu sering terbangun saat tidur, hal tersebut mempengaruhi terganggunya kualitas tidur ibu yang mengalami preeklamsi [2].

Menurut Potter dan Perry tahun 2010 beberapa faktor yang mempengaruhi kualitas tidur adalah faktor fisiologis, faktor psikologis, lingkungan dan gaya hidup. Dampak dari faktor fisiologis adalah penurunan kegiatan sehari-hari, rasa lemah, lelah, daya tahan tubuh menurun dan tanda-tanda vital tidak stabil. Dampak dari faktor psikologis adalah depresi, cemas, stres dan sulit untuk konsentrasi. Kualitas tidur yang baik berpengaruh pada kinerja optimal neurokognitif dan psikomotor, begitu juga kesehatan fisik dan mental. Salah satu penyebab terjadinya kelelahan dan masalah tidur saat kehamilan adalah perubahan kadar hormon. Meningkatnya kadar progesteron menyebabkan kantuk di siang hari $[7,8]$.

Berdasarkan data National Sleep Foundation jumlah ibu hamil trimester tiga selalu terbangun di malam hari sebesar $97,3 \%$, ratarata 3-11 kali setiap malam. Menurut data hasil survei National Sleep Foundation, jumlah ibu hamil di Amerika yang mengalami gangguan tidur sebesar $78 \%$ dan hanya $1,9 \%$ ibu hamil yang tidak terbangun di malam hari saat usia kehamilan trimester III. gangguan pola tidur terjadi pada trimester I 13\% hingga mencapai $80 \%$, sedangkan pada trimester III mengalami peningkatan dari $66 \%$ meningkat hingga 97\% (Venugopal dkk., 2018) [8,9]. Menurut Safriani tahun 2017 prevalensi gangguan tidur di Indonesia terhadap ibu hamil cukup besar kirakira 64 dan $42 \%$ terjadi pada ibu hamil yang menderita preeklamsi [10].

Kualitas tidur dipengaruhi oleh beberapa faktor yaitu adalah jenis kelamin dan usia, aktivitas fisik, penyakit, gaya hidup, lingkungan fisik dan stres psikologis. Adanya kecemasan dan stres dapat menyebabkan peningkatan aktivitas simpatis sehingga mengalami gangguan tidur. Menurut Penelitian Fatimah tahun 2017 hubungan stres terhadap peningkatan tekanan darah tinggi pada ibu hamil menunjukkan pasien hipertensi dengan tingkat stres sedang sebagian besar mengalami kekambuhan peningkatan tekanan darah kadang-kadang yaitu sebanyak 34 responden $(64 \%)$, sedangkan pada tingkat stres berat sebagian besar mengalami kekambuhan peningkatan tekanan darah sering yaitu sebanyak 11 responden (65\%). Berdasarkan 
data tersebut, dapat dinyatakan bahwa semakin tinggi tingkat stres responden maka tingkat kekambuhan hipertensinya semakin sering, sehingga hipertensi merupakan salah satu tanda yang paling sering pada preeklamsi [11].

Stres pada ibu hamil akan memproduksi hormone adrenalin dan mengeluarkan hormone kortisol. Meningkatkan kortisol akan melumpuhkan sistem kekebalan tubuh sehingga tubuh ibu hamil menjadi rentan terhadap berbagai penyakit dan gangguan, seperti gangguan jantung, hipertensi, saluran cerna, preeklampsia, dan sebagainya. Preeklampsia bisa terjadi karena jantung akan melakukan kompensasi dengan cara meningkatkan cardiac output yang menyebabkan hipertensi [12].

Menurut Kasenda, dkk 2017 berpendapat bahwa ibu yang mengalami stres akan mempengaruhi kualitas tidurnya. Ibu hamil yang memiliki gangguan tidur dengan tidur terlalu sedikit atau terlalu banyak akan memicu tekanan darah. Hal ini disebabkan adanya proses hemostasis yang berperan dalam pengaturan keseimbangan tekanan darah pada ibu hami. Istirahat yang cukup dapat menghindari ibu hamil dari kondisi stres, karena saat stres produksi hormon adrenalin meningkat sehingga menyebabkan penyempitan pembuluh darah (vasokonstriksi) dan prningkatan inflamasi tubuh [13]. Menurut Sitohang dkk tahun 2016 mengatakan bahwa peningkatan tekanan darah cenderung terjadi pada orang yang kurang tidur karena pada ibu hamil yang kurang tidur akan memicu peningkatan homeostasis. Hasil penelitian tersebut menyebabkan bahwa sebagian besar ibu hamil dengan preeeklamsi memiliki tidur dengan rata-rata kurang dari 6 jam per hari yang dapat meningkatkan risiko mengidap hipertensi sebesar $37 \%$ [14].

Macam macam gangguan tidur selama kehamilan yaitu gangguan pada durasi tidur, mengantuk, apnea, hypopnea. Hal tersebut karena perubahan hormon saat hamil sehingga menyebabkan rahim yang membesar, sakit punggung, gerakan janin yang dapat mempengaruhi perubahan pola tidur [15].

Peran perawat diperlukan dalam mengetahui permasalahan ini, dimana perawat bisa memberikan edukasi mengenai perilaku coping untuk mengatasi stres selama kehamilan berlangsung, hal tersebut saling berhubungan ketika coping tidak efektif maka stres akan meningkat, selain itu perawat dapat memberikan informasi pada ibu preeklamsi agar menciptakan tidur yang berkualitas.

Berdasarkan latar belakang $\mathrm{di}$ atas, e-Journal Pustaka Kesehatan, vol. 9 (no. 1), Januari 2021 mengenai hubungan tingkat stres dengan kualitas tidur pada ibu preeklamsi yang menyatakan bahwa kualitas tidur ibu hamil yang buruk dapat memicu terjadinya stres dan hal ini dapat meningkatkan tekanan darah sehingga berpotensi terjadinya preeklamsi. Pada variabel tingkat stres dan kualitas tidur sudah ada penelitian yang dilakukan pada ibu hamil namun pada variabel tersebut masih belumn yang ada penelitia dilakukan pada ibu preeklamsi. Oleh karena itu, peneliti ingin meneliti lebih jauh mengenai hubungan tingkat stres dengan kualitas tidur pada ibu preeklamsi.

\section{Metode Penelitian}

Penelitian ini merupakan penelitian observational analitik dengan menggunakan desain cross-sectional untuk meneliti adanya korelasi antara hubungan tingkat strea dengan kualitas tidur ib preeklamsi. Populasi berjumlah 31 ibu preeklamsi. Tehnik sampling yang digunakan adalah non-probability sampling dengan total sampling.

Penelitian dilakukan pada bulan Juli hingga Agustus 2019. Uji normalitas menggunakan uji shapiro wilk dengan hasil berdistribusi tidak normal yaitu 0,023 . Korelasi antar variabel interval dan interval menggunakan uji spearman.

\section{Hasil Penelitian} tabel berikut.

Hasil penelitian disajikan dalam table-

Tabel 1. Karakteristik ibu preeklamsi

\begin{tabular}{lcc}
\hline \multicolumn{1}{c}{ Variabel } & $\begin{array}{c}\text { Frekuensi } \\
\text { (orang) }\end{array}$ & $\begin{array}{c}\text { Persentase } \\
\text { (\%) }\end{array}$ \\
\hline Umur & & \\
$<20$ tahun & 5 & 16,1 \\
21-35 tahun & 24 & 77,4 \\
$>35$ tahun & 2 & 6,5 \\
\hline Pendidikan & & \\
SD & 8 & 25,8 \\
SMP & 10 & 32,3 \\
SMA & 11 & 35,5 \\
PT & 2 & 6,4 \\
\hline Pekerjaan & & \\
PNS & 1 & 3,2 \\
Swasta & 8 & 25,8 \\
Wiraswasta & 7 & 22,6 \\
lbu Rumah & 15 & 48,4 \\
Tangga & & \\
\hline Riwayat & & \\
Preeklamsi & & \\
\hline 1
\end{tabular}




\begin{tabular}{lll}
\hline Memiliki & & \\
Riwayat & 10 & 32,3 \\
Preeklamsi & & \\
Tidak Memiliki & 21 & 67,7 \\
Riwayat & & \\
Preeklamsi & & \\
\hline
\end{tabular}

Sumber : Data Primer Peneliti, Agustus 2019

Berdasarkan tabel di atas menjelaskan bawah jumlah responden sebanyak 31 responden dari bulan juli hingga agustus 2019 . Sebagian besar responden berumur 20-35 tahun sebanyak 24 responden $(77,4 \%)$. Tingkat pendidikan responden didapatkan presentase paling besar yaitu SMA sebanyak 11 (35,5\%). Sebagian besar responden merupakan seorang ibu rumah tangga yaitu sebanyak $15(48,4 \%)$. Jumlah responden yang tidak memiliki riwayat preeklaamsi sebanyak $21(67,7 \%)$.

Tabel 2. Distribusi tingkat stres di Wilayah Kerja Puskesmas Tempurejo

\begin{tabular}{|c|c|c|c|}
\hline No. & Kategori & $\begin{array}{c}\text { Frekuensi } \\
\text { (orang) }\end{array}$ & Persentase \\
\hline 1. & Normal & 1 & 3,2 \\
\hline 2. & $\begin{array}{l}\text { Stres } \\
\text { Ringan }\end{array}$ & 19 & 61,3 \\
\hline 3. & $\begin{array}{l}\text { Stres } \\
\text { Sedang }\end{array}$ & 8 & 25,8 \\
\hline 4. & Stres Berat & 3 & 9,7 \\
\hline & Total & 31 & 100 \\
\hline \multicolumn{4}{|c|}{ Sumber : Data Primer Peneliti, Agustus 2019} \\
\hline \multicolumn{4}{|c|}{$\begin{array}{l}\text { Dari tabel diatas diketahui bahwa hasi } \\
\text { tertinggi tingkat stres yaitu mengalami stres } \\
\text { ringan dengan hasil } 19(61,3 \%) \text { dan jumlah } \\
\text { terendah yaitu } 1 \text { orang }(9,7 \%) \text { mengalami stres } \\
\text { berat. }\end{array}$} \\
\hline
\end{tabular}

Tabel 3 Distribusi Kualitas Tidur pada Ibu Preeklamsi di Wilayah Kerja Puskesmas Tempurejo (Agustus, 2019; $\mathrm{n}=31$ )

\begin{tabular}{llc}
\hline Variabel & Kategori & $\begin{array}{c}\text { Frekuens } \\
\text { i } \\
\text { (Orang) }\end{array}$ \\
\hline Kualitas & 1.Baik & 5 \\
Tidur & 2.Buruk & 26 \\
\hline Total & & 31
\end{tabular}

Sumber : Data Primer Peneliti, Agustus 2019

e-Journal Pustaka Kesehatan, vol. 9 (no. 1), Januari 2021
Distribusi kualitas tidur mengambarkan bahwa mayoritas ibu preeklasmi mengalami kualitas tidur yang buruk $26(83,9 \%)$ responden.

Tabel 4 Hasil analisa hubungan antara tingkat stres dan kualitas tidur pada ibu preeklamsi di Wilayah Kerja Puskesmas Tempurejo Kabupaten Jember

\begin{tabular}{ccc}
\hline Variabel & $R$ & $p$ Value \\
\cline { 1 - 1 } Tingkat Stres & 0,894 & 0,001
\end{tabular}

Sumber : Data Primer Peneliti, Agustus 2019

Hasil analisa data menggunakan uji statistik spearmen didapatkan $p$ value 0,001 kurang dari nilai significant 0,05 yang artinya terdapat hubungan antara tingkat stres dengan kualitas tidur atau Ha gagal ditolak. Nilai $r=0,894$ mengartikan bahwa korelasi antara tingkat stres dengan kualitas tidur pada ibu preeklamsi memiliki arah korelasi positif dengan kekuatan korelasi sangat kuat. Arah korelasi positif menunjukkan bahwa semakin tinggi nilai tingkat stres maka kualitas tidur yang dialami semakin buruk.

\section{Pembahasan}

\section{Karakteristik Responden}

Hasil Penelitian menunjukkan bahwa sebagian besar ibu preeklamsi di Wilayah Kerja Puskesmas Tempurejo berusia 20-35 tahun. Hal tersebut menunjukkan bahwa ibu berada pada usia reproduktif. Pada usia reproduktif merupakan usia yang baik untuk hamil, dimana pada usia reproduktif ini alat reproduksi wanita telah berkembang dan berfungsi secara maksimal. Sebaliknya, pada usia $<20$ tahun reproduksi wanita pada masa itu belum sepenuhnya matang dan pada usia $>35$ tahun terjadi penurunan fungsi alat reproduksi, usia tersebut kurang baik untuk hamil karena kehamilan pada usia tersebut memiliki resiko tinggi [16]. Berdasarkan hasil yang didapatkan pada penelitian ini bahwa usia ibu lebih banyak pada usia reproduktif yaitu 20-35 tahun, hal ini dikarenakan populasi ibu preeklamsi lebih banyak berada pada usia 20-35 tahun.

Hasil dari penelitian menunjukkan kurang dari setengah ibu preeklamsi di Wilayah Kerja Puskesmas Tempurejo berpendidikan SMA. Pendidikan ibu yang tinggi didapat seiring dengan kemajuan ilmu dan teknologi serta adanya program pemerintah yang mewajibkan 
sekolah 9 tahun. Seseorang yang berpendidikan lebih tinggi cenderung mempunyai pemikiran yang baik karena semakin tinggi tingkat pendidikan semakin bertambah pula pengetahuan yang di dapat [17]. Hasil penelitian ini sesuai dengan populasi di Wilayah Kerja Puskesmas Tempurejo dimana ibu sudah banyak menempuh tingkat pendidikan yang tinggi.

Pada karakteristik pekerjaan hampir dari setengah responden adalah ibu rumah tangga, dimana ibu banyak menghabiskan waktu aktifitas sehari-hari di rumah. Ibu rumah tangga memiliki resiko komplikasi lebih kecil dibandingkan ibu yang bekerja, karena selain bekerja ibu juga mempunyai tanggung jawab pekerjaan rumah tangganya, sehingga ibu yang bekerja mempunyai resiko komplikasi yang meningkat dengan tingkat stres yang tinggi. Dalam jangka pendek, tingkat stres akan menyebabkan gejala rasa lemas, kurang tidur, perasaan cemas berlebihan, nafsu makan terganggu. Fakta dilapangan ibu lebih banyak melakukan aktifitas di rumah karena ibu sudah bergantung pada suami yang mencari nafkah.

Berdasarkan hasil penelitian didapatkan lebih dari setengah jumlah responden yang diteliti sebagian besar responden tidak memiliki riwayat preeklamsi dibandingan dengan responden yang memiliki riwayat preeklamsi, namun yang memiliki riwayat preeklamsi juga banyak 10 dari 31 ibu mempunyai riwayat preeklamasi. Ibu hamil akan yang memiliki risiko lebih besar mengalami preeklamsi pada ibu yang pernah mengalami preeklamsi pada kehamilan sebelumnya (Cunningham, 2013) [18]. Pernyataan tersebut sejalan dengan Radjamuda dan Montolalu tahun 2014 bahwa ibu yang pernah mengalami preeklamsi sebelumnya akan meningkat mendapatkan preeklamsi pada kehamilan berikutnya. Kejadian preeklamsi akan meningkat pada kehamilan kedua bila ada kehamilan dengan jarak anak yang terlalu jauh. Jika ibu memiliki Riwayat preeklamsi kemungkinan primigravida akan meningkat empat kali. Hipertensi kronis memiliki resiko $10-25 \%$ mengalami preeklamsi dibandingkan dengan populasi umum. Resiko ini meningkat menjadi 31\% pada wanita dengan durasi hipertensi yang lebih lama minimal empat tahun atau lebih dengan kondisi hipertensi berat.

\section{Tingkat Stres pada lbu Preeklamsi di Wilayah Kerja Puskesmas Tempurejo Kabupaten Jember}

Pada penelitian ini menunjukkan bahwa 30 dari 31 ibu preeklamsi mengalami stres yang e-Journal Pustaka Kesehatan, vol. 9 (no. 1), Januari 2021 dikategorikan pada stres ringan, stres sedang, dan stres berat dan yang paling banyak mengalami stres yaitu pada kategori stres ringan dan stres sedang. Penelitian ini sejalan dengan penelitian Khayati dan Veftisia tahun 2018 bahwa stres yang terjadi dapat dipengaruhi oleh gaya hidup ibu yang tidak sehat, di mana ibu hamil tidak memperhatikan kondisi kehamilannya yang menyebabkan kondisi tidak sehat seperti preeklamsi. Stres merupakan suatu kondisi yang terjadi karena adanya perubahan lingkungan yang dianggap sebagai suatu hal yang mengancam atau merusak keseimbangan mental seseorang.

Hal tersebut sesuai dengan keadaan pada saat peneliti melakukan penelitian, ibu terlihat mimik wajah begitu tegang pada saat peneliti memberikan kuesioner. Keadaan ibu dapat dilihat dari bagaimana reaksi terhadap hal-hal yang dianggap menggangu atau memberatkan. Hal ini juga sejalan dengan penelitian yang dilakukan oleh Taslim, dkk tahun 2016 yang menyebutkan bahwa terdapat hubungan antara stres dengan kejadian hipertensi grade 1 dan grade 2. Secara psikologis juga ada beberapa yang menyebabkan stres yaitu ibu yang belum terbiasa dengan keadaannya yang membuat hormon kortisol meningkat sehingga ibu merasa kesal atau sedih. Selain itu ibu juga akan mengalami morning sickness yang akan mengakibatkan stres dan biasanya ibu dengan preeklamsi pada trimester 3 stresnya semakin meningkat dikarenakan ibu mudah merasa lelah dan posisi tidur yang kurang nyaman juga semakin dekatnya waktu persalinan yang dapat membuat tingkat stres ibu semakin tinggi [19].

Stres juga dapat disebabkan karena adanya perubahan hormon yang berdampak mempengaruhi mood ibu sehingga ibu merasa kesal, jenuh atau sedih. Stres dapat memicu kejadian preeklamsi melalui beberapa mekanisme yaitu, stres akan mengaktifkan hipotalamus, kemudian melepaskan rantai peristiwa biokimia yang mengakibatkan desakan adrenalin dan non adrenalin ke dalam sistem dan diikuti oleh peningkatan hormon kortisol dan $\mathrm{CRH}$ sehingga akan menyebabkan ketengangan otot hingga terjadi vasokontriksi atau kontraksi pada dinding otot yang akan menyumbat aliran darah. Maka tekanan darah akan meningkat denyut jantung meningkat dan sirkulasi darah pada utero plasenta menurun yang mengakibatkan hipoksia plasenta dan disfungsi endotel hingga terjadilah hipertensi, edema, peningkatan proteinuria pada ibu yang merupakan tanda-tanda dari preeklamsi. Menurut taksonomi diagnosa keperawatan 
pada buku North American Nursing Diagnosis Association International (NANDA) pada tahun 2015 diagnosa keperawatan yang sesuai dengan permasalahan yang ada adalah Ansietas, diagnosa tersebut terdapat pada domain 9 mengenai Koping/Toleransi stres pada kelas 2 mengenai respon kopingdan memiliki kode diagnosa 00146. Ansietas adalah perasaan tidak nyaman atau kekhawatiran yang samar disertai respon otonom (sumber sering kali tidak spesifik atau tidak diketahui oleh individu); perasaan takut yang disebabkan oleh antisipasi terhadap bahaya. Hal ini merupakan isyarat kewaspadaan yang memperingatkan individu akan adanya bahaya dan memampukan individu untuk bertindak menghadapi ancaman. Menurut buku Nursing Outcome Classification (NOC) 2013 batasan karakteristik yaitu tingkat rasa takut yang meliputi distres, kesulitan berkonsentrasi, kelhawatiran berlebihan tentang peristiwa kehidupan, peningkatan tekanan darah, wajah tegang, kelelahan, ketakutan dan kepanikan. Sehingga berdasarkan buku Nursing Intervention Classification pada tahun 2013 perawat dalam hal ini dapat memberikan intervensi terapi rileksasi seperti konseling,hipnosis, terapi musik, relaksasi otot progresif serta dukungan emosional. Mendengarkan musik merupakan tehnik yang efektif untuk mengalihkan perhatian seseorang terhadap stres yang berlebih. Hipnosis bermanfaat untuk memotivasi diri, mengatasi berbagai gangguan emosional, meningkatkan kualitas diri, mebantu proses penyembuhan dan dalam dunia medis sangat berguna bagi penanganan klien $[18,19,20]$.

\section{Kualitas Tidur pada Ibu Preeklamsi di Wilayah Kerja Puskesmas Tempurejo Kabupaten Jember}

Pada hasil penelitian ini menunjukkan bahwa kualitas tidur pada ibu preeklamsi dominan memiliki kualitas tidur buruk. Berdasarkan hasil penelitian dapat diketahui bahwa total nilai kualitas tidur dengan menggunakan kuesioner PSQI pada ibu preeklamsi sebagian besar responden mengalami kualitas tidur yang buruk. Penelitian tersebut didukung oleh penelitian Sitohang (2016) sebanyak $16(72,3 \%)$ ibu preeklamsi mempunyai kualitas tidur yang buruk. Beberapa faktor yang mempengaruhi kualitas tidur yaitu faktor fisiologis, psikologis, lingkungan dan gaya hidup. Dari faktor fisiologis mengakibatkan aktivitas seharihari menurun, rasa lemah, lelah, daya tahan tubuh menurun, dan ketidakstabilan tanda tanda vital, sedangkan dari faktor psikologis berdampak e-Journal Pustaka Kesehatan, vol. 9 (no. 1), Januari 2021 depresi, cemas, dan sulit untuk konsentrasi [7]. Kualitas tidur merupakan ukuran seseorang mendapatkan kemudahan untuk memulai tidur, mampu mempertahankan tidur, dan merasa segar setelah bangun dari tidur. Keaadaan saat penelitian banyak ibu mengalami kualitas tidur yang buruk keluhan yang muncul seperti ibu sulit masuk tidur atau kesulitan mempertahankan tidur dalam kurun waktu tertentu, sehingga menimbulkan gangguan dalam berbagai fungsi sosial, pekerjaan, ataupun fungsi-fungsi kehidupan lainnya. Ibu juga banyak yang mengeluh tidurnya terganggu karena sering bangun di malam hari untuk buang air kecil. Pada saat dilakukan penelitian ibu terlihat mimik wajah kantung mata menghitam, kelopak mata bengkak, dan ibu malas bebicara. Menurut Sitohang, dkk (2016) kualitas tidur yang buruk akan memicu peningkatan homeostasis. Seseorang yang menglamai kualitas tidur yang buruk dapat disebabkan oleh stres situsional seperti masalah keluarga, kerja atau sekolah, kekhawatiran [14].

Pernyataan mengenai keluhan yang dialami oleh ibu tersebut menunjukkan bahwa kualitas tidur ibu buruk dan kurang puas dengan kedaan tidurnya. Seseorang yang mengalami ketidakpuasan dalam tidurnya menurut taksonomi diagnosa keperawatan yang sesusai dengan permasalahan yang ada adalah gangguan pola tidur. Diagnosa tersebut terdapat pada domain 4 mengenai aktivitas/ istirahat pada kelas 1 mengenai tidur / istirahat dengan kode diagnosa 000198. Gangguan pola tidur adalah gangguan pada jumlah waktu dan kualitas tidur akibat faktor eksternal. Menurut Nursing Outcome Classification (NOC) tahun 2013 batasan karakteristik tidur berkualitas, tidak mengalami kelelahan atau efek lain yang mengganggu. Berdasarkan Nursing Intervention Classification (NIC) tahun 2013 dapat dilakukan intervensi seperti terapi relaksasi, peningkatan tidur berupa Relaksasi Otot Progresif. Relaksasi otot progresif adalah latihan relaksasi yang didahului dengan menegangkan tubuh secara sistematis dan kemudian merelaksasikan semua otot tubuh. Dilakukan relaksasi otot progresif bertujuan untuk meningkatkan rasa nyaman, memberikan rasa rileks,mengurangi rasa nyeri. Relaksasi otot progresif mampu meningkatkan kualitas tidur ibu selain itu juga menurunkan sistolik ibu sehingga membuat rasa nyeri berkurangdan meningkat hormon endorfin pada tubuh. Dengan dilakukannya Relaksasi Otot Progresif guna meningkat kualitas tidur yang baik pada ibu preeklamsi $[19,20,21]$. 


\section{Hubungan antara Tingkat Stres dengan Kualitas Tidur pada Ibu Preeklamsi}

Analisis hubungan pada penelitian ini menunjukkan bahwa sebagian besar responden yaitu sebanyak $19(61 \%)$ mengalami stres ringan, $8(25,8 \%)$ mengalami stres sedang dan $3(9,7 \%)$ mengalami stres berat dari hasil penelitian yang mengalami stres mempunyai kualitas tidur yang buruk yaitu sebanyak $26(83,9 \%)$ dan sisanya kualitas tidur baik. Korelasi menggunakan uji Spearman yang menunjukkan bahwa $p$ value 0,001 kurang dari nilai significant 0,05 yang artinya terdapat hubungan antara tingkat stres dengan kualitas tidur atau Ha diterima dan kedua variabel tersebut memiliki arah korelasi yang positif dengan korelasi sangat kuat. Hasil tersebut dapat diartikan bahwa terdapat hubungan antara tingkat stres dengan kualitas tidur pada ibu preeklamsi di Wilayah Kerja Puskesmas Temourejo Kabupaten Jember. Saat penelitian didapatkan 30 dari 31 ibu mengalami Stres, dan yang paling banyak yaitu pada stres ringan dan stres sedang. Ibu yang mengalami stres ringan dan sedang, kualitas tidurnya buruk.

Hasil penelitian ini sependapat dengan penelitian Kasenda dkk tahun 2017 bahwa ada hubungan antara stres dengan kejadian insomnia. lbu yang mengalami stres kualitas tidurnya akan terganggu, stres yang dialami oleh ibu berhubungan dengan faktor fisologis seperti perubahan fisiologis saat kehamilan, peningkatan urinari, proses kelahiran yang semakin dekat serta bebagai faktor yang menyebabkan kualitas tidur ibu buruk serta berbagai faktor lain pun dapat mengakibatkan ibu mengalami stres sehingga kualitas tidur ibu menjadi terganggu sehingga kesehatan juga terganggu [13].

Ketika Stres proses hemostasis yang berperan dalam pengaturan keseimbangan tekanan darah pada ibu hamil. Istirahat yang cukup dapat menghindari ibu hamil dari kondisi stres, karena saat stres produksi hormon adrenalin meningkat sehingga menyebabkan penyempitan pembuluh darah (vasokonstriksi) dan peningkatan inflamasi tubuh [14]. Kualitas tidur yang buruk dapat disebabkan oleh stres situsional seperti masalah keluarga, kerja atau sekolah, penyakit atau kehilangan orang yang dicintai. Keadaan stres dapat menyebabkan kesulitan kronik untuk tidur yang cukup yang mungkin disebabkan oleh kekhawatiran, stres, dan kecemasan. Fakta di lapangan ibu banyak mengeluh ketakutan akan persalinan, faktor biaya persalinan dan adapula yang trauma karena persalinan yang sebelumnya mengalami e-Journal Pustaka Kesehatan, vol. 9 (no. 1), Januari 2021 tekanan darah tinggi serta ibu sering mengalami gangguan tidur seperti terbangun karena sering buang air kecil, durasi tidur kurang baik sehingga terdapat kantung mata akibat kurang tidur. Stres tidak hanya dialami pada wanita hamil yang resiko tinggi saja, stres juga dapat dialami oleh ibu hamil yang normal, namun ibu hamil yang mengalami resiko tinggi seperti preeklamsi akan mengalami stres sehingga dapat menyebabkan kualitas tidur ibu menjadi buruk yang dapat muncul tanda gejala seperti sakit kepala, ketegangan otot, nyeri leher atau punggung dan kesulitan untuk tidur.

Menurut taksonomi diagnosa keperawatan pada buku North American Nursing Diagnosis International (NANDA) tahun 2015 diagnosa keperawatan yang sesuai dengan permasalahan yang adalah gangguan rasa nyaman. Diagnosa tersebut ada ada pada domain 12 mengenai kenyamanan, pada kelas 1 mengenai kenyamanan fisik dengan kode 00214. Gangguan rasa nyaman adalah merasa kurang nyaman, lega dan sempurna dalam dimensi fisik, psikospiritual, lingkungan, budaya dan sosial.

Menurut Nursing Outcome Classification tahun 2013 batasan karakteristik ibu preeklamsi yang mengalami gangguan rasa nyaman adalah faktor-faktor yang mengganggu tingkat stres dan tidur. Pada batasan karakteristik tingkat stres meliputi peningkatan tekanan darah, gangguan tidur, mudah marah, kecemasan, ketidakmampuan berkonsentrasi, sering buang urin. Pada batasan karakteristik tidur meliputi jam tidur, pola tidur, kualitas tidur, efisiensi tidur, mudah bangun pada saat yang tepat, tidur dari awal sampai habis di malam hari secara konsisten, tidur rutin. Sehingga Berdasarkan Nursing Intervention Classification tahun 2013 intervensi yang dapat diberikan pada ibu preeklamsi mengenai gangguan rasa nyaman adalah

Manajemen lingkungan; Kenyamanan seperti terapi rileksasi. Contoh terapi rileksasi yang dapat dilakukan pada ibu yaitu senam yoga. Terapi rileksasi dapat dilakukan dengan cara menciptakan lingkungan yang nyaman dan tenang untuk ibu, relaksasi nafas dalam, relaksasi otot progresif,dan terapi musik. Relakasasi otot progresif adalah relaksasi yang dilakukan dengan cara melakukan peregangan otot dan mengistirahatkan kembali secara bertahap dan teratur sehingga memberikan keseimbangan emosi dan ketenangan pikiran atau biasa disbut senam yoga $[19,20,21]$. 


\section{Simpulan dan Saran}

Penelitian ini menunjukkan sebagian besar ibu preeklamsi berada pada usia produktif yaitu berumur 20-35 tahun, paling banyak berpendidikan SMA, sebagian besar ibu rumah tangga dan lebih dari setengah responden tidak mempunyai riwayat preeklamsi yang memiliki riwayat preeklamsi. Mayoritas ibu preeklamsi mengalami stres kategori ringan. Sebanyak 26 responden mengalami kualitas tidur buruk. Terdapat hubungan antara tingkat stres dengan kualitas tidur ibu preeklamsi di Wilayah Kerja Puskesmas Tempurejo Kabupaten Jember.

Peneliti selanjutnya diharapkan dapat melakukan intervensi yang dapat mengurangi tingkat stres dengan kualitas tidur pada ibu preeklamsi sehingga dapat mengurangi faktorfaktor preeklamsi. Perlu penelitian tentang pemberian intervensi pada ibu preeklamsi misalnya hipnoterapi dan relaksasi otot progersif untuk membantu memberikan teknik relaksasi pada ibu agar mengurangi tingkat stres pada ibu dan meningkat kualitas tidur ibu menjadi baik

\section{Daftar Pustaka}

[1] Salmah dkk. (2006). Asuhan Kebidanan Antenatal. Cetakan. Ke-1. Jakarta. EGC.

[2] Shinta LE, dkk. 2016. Pengaruh Kualitas Tidur Pada Ibu Hamil Dengan Kejadian Preeklamsia.. Journal of Midwifery. 1:1 . 3544.

[3] Sukarni IK dan Wahyu P. 2013. Buku Ajar Keperawatan Maternitas. Yogyakarta: Nuha Medika.

[4] Kemenkes RI. 2015. Profil Kesehatan Indonesia Tahun 2014. Diunduh tanggal 27 Juni 2019 dari http://www.depkes.go.id /resources/download/pusdatin/lain-lain/Data dan Informasi Kesehatan Profil Kesehatan Indonesia 2016.

[5] Dinas Kesehatan Provinsi Jatim. 2015. Profi I Kesehatan Provinsi Jawa Timur Tahun 2014. Surabaya

[6] Lesmana RD. 2018. Gambaran Faktor Risiko Preeklampsia Pada lbu Hamil Di Puskesmas Tempurejo. Skripsi. Jember: Universitas Jember.

[7] Potter dan Perry. 2010. Fundamental Keperawatan : Konsep, Proses, dan Praktik. Edisi 7. Jakarta : EGC.

e-Journal Pustaka Kesehatan, vol. 9 (no. 1), Januari 2021
[8] Venugopal L, Rajendran P, dan Parghavi. 2018. A Study on Assesment of Sleep Quality in South Indian Pregnant Woman. International Journal of Research in Medical Sciences .3197-320142:57-64.

[9] National Sleep Foundation.2007, women and sleep 2. USA. Dilihat tanggal 20 Februari 2019 http://www.Sleepfoundation.org

[10] Safriani I. 2017. Pengaruh Senam Yoga Terhadap Kualitas Tidur Ibu Hamil Trimester III di Wilayah Kerja Puskesmas Plandaan Jombang. Skripsi. Jombang: Sekolah Tinggi IImu Kesehatan Insan Cendekia Medika

[11] Fatimah IN. 2017. Hubungan Pola Makan dan Stres dengan Kejadian Hipertensi Pada Ibu Hamil di Wilayah Kerja Puskesmas Tongauna Kabupaten Konawe Provinsi Sulawesi Tenggara. Skripsi. Kendari: Politeknik Kesehatan Kendari

[12] Khayati YN dan Veftisia V. 2018. Hubungan Stres dan Pekerjaan dengan Preeklampsia di Wilayah Kabupaten Semarang. Indonesia Journal of Midwivery. 1:1.

[13] Kasenda $\mathrm{P}$, Wongouw $\mathrm{H}$, dan Lolong J. 2017. Hubungan Stres dengan Kejadian Insomnia pada lbu Hamil di Puskesmas Bahu Kota Manado. E-Journal Keperawatan . 5:1.

[14] Sitohang PC, dkk. 2016. Hubungan Pola Makan dan Kecukupan Istirahat Tidur dengan Kejadian Hipertensi Pada Ibu Hamil Di Wilayah Kerja Puskesmas Biromari. Jurnal Kesehatan Tadulako. 2;1

[15] Pitault FB, dkk. 2015. Sleep Pattern During Pregnancy and Maternal Depression: Study of Aube Cohort. Sleep Disorders Management. 1:1

[16] Khatarina T, dan Lit K. 2016. Hubungan Karakteristik Ibu hamil dengan Kejadian Preeklamsia di Rumah Sakit Bhayangkara Pontianak Tahun 2015. Jurnal Kesehatan. Vol 6 (1): 51-57.

[17] Purwantini D. 2018. Hubungan Tingkat Stres dengan Kualitas Tidur pada Ibu Preeklamsi di RSUD Caruban di Kabupaten Madiun. Skripsi. Jombang: Sekolah Tinggi IImu Kesehatan Insan Cendekia Medika. 
[18] Cunningham FG. 2013. Hipertensi Dalam Kehamilan. Jakarta : Buku Kedokteran EGC.

[19] Nanda. 2015. Diagnosis Keperawatan Definisi \& Klasifikasi 2015-2017 Edisi 10 Editor T Heather Herman, Shigemi Kamitsuru. Jakarta : EGC
[20] Bulechek MG. 2016. Edisi enam Nursing Intervention Classification (NIC). Singapore : Elsevier Golbal Right.

[21] Bulechek MG. 2016. Edisi enam Nursing Outcome Classification (NOC). Singapore : Elsevier Golbal Right. 